\title{
The influence of sediment size, relative grain size and channel slope on initiation of sediment motion in boulder bed rivers. A lichenometric study
}

\author{
Frederic Gob, ${ }^{1 *}$ Jean-Paul Bravard ${ }^{2}$ and François Petit ${ }^{3}$ \\ ${ }^{1}$ Cemagref, Hydrosystems and Bioprocesses, Antony, France \\ 2 University of Lyon 2, Bron, France \\ 3 Department of Geography, University of Liège, Liège, Belgium
}

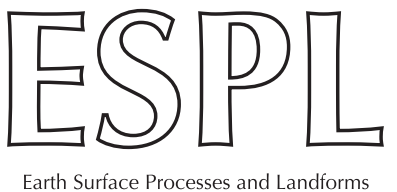

ABSTRACT: Sediment transport of four boulder bed rivers is studied using lichenometry. The presence of lichens on boulders in the river channel is used to date the last mobilization of the blocks. Using size frequency diagrams and regional growth curves calibrated with dated reference points it is possible to determine the flood event responsible for the last mobilization of each boulder with lichens present. The specific stream power of flood events over the last 60 years is then calculated, and thresholds of sediment transport based on the sediment size are calculated. The results from the four studied rivers are compared to similar relationships in the literature. Sediment motion thresholds appear to be very variable within the same type of river (mountainous boulder bed rivers). The critical specific stream power necessary to mobilize a particle of a given diameter may vary by up to 10 times from one river to the next. Bed sediment size and river slope may explain this large range of stream powers. Calculation of the relative size of the transported particles $\left(D_{\mathrm{i}} / D_{50}\right)$ also shows that both hiding and protrusion effects, as well as channels slope, are important factors in sediment transport. Copyright (C) 2010 John Wiley \& Sons, Ltd.

KEYWORDS: boulder bed stream; lichenometry; sediment transport; relative grain size; critical stream power

\section{Introduction}

Mountainous streams flow in confined valleys which induce extremely high values of velocity, shear stress and specific stream power during floods (Baker and Kochel, 1988). The narrowness of the valley is compensated by the high water depth which plays a key role in sediment transport. Specific criteria for the mobilization and transportation of large boulders and blocks are, however, relatively unknown. While the movement of large particles has been observed many times, the processes which govern sediment mobilization and transportation over very rough river beds are still not fully understood (Carling and Tinkler, 1998). Until recently, only a handful of studies had proposed mobilization thresholds for particles above $500 \mathrm{~mm}$ in diameter. Those of Costa (1983) and Williams (1983) have been widely used, mainly for paleodischarge reconstruction from the size of the bed particles. More recently a study by Lenzi et al. (2006) and lichenometric studies (Gob et al., 2003; Jacob et al., 2006) have proposed new large boulder motion thresholds. The relationships proposed in these studies (with the exception of Lenzi et al., 2006) link the transported particle size $\left(D_{\mathrm{i}}\right)$ to the specific stream power needed for mobilization of this particle i (critical stream power $\left.\omega_{\mathrm{ci}}\right)$ :

$$
\omega_{\mathrm{ci}}=\mathrm{a} D_{\mathrm{i}}^{b}
$$

The specific stream power $(\omega)$ has been defined by Bagnold (1977, 1980). This is a simple indicator of river dynamics which has been used by several authors (e.g. Costa, 1983; Williams, 1983; Hassan et al., 1992; Gintz et al., 1996; Petit et al., 2005). In comparison to other descriptors such as shear stress, specific stream power has the advantage of being easier to measure, notably because the water depth does not need to be known. Indeed, it is a function of only the discharge $(Q$, in $\left.\mathrm{m}^{3} / \mathrm{s}\right)$, slope $(s$, in $\mathrm{m} / \mathrm{m})$ and width $(w$, in $\mathrm{m})$ :

$$
\omega=\rho g Q s / w
$$

with $\omega$ the specific stream power (in $\mathrm{W} / \mathrm{m}^{2}$ ), $\rho$ the fluid density (in $\mathrm{kg} / \mathrm{m}^{3}$ ) and $g$ the acceleration due to gravity (in $\mathrm{m} / \mathrm{s}^{2}$ ). The shear stress $\left(\tau\right.$, in $\left.\mathrm{N} / \mathrm{m}^{2}\right)$ is defined as:

$$
\tau=\rho g R_{\mathrm{h}} S
$$


with $R_{\mathrm{h}}$ the hydraulic radius (in $\mathrm{m}$ ). Lee and Ferguson (2002) have shown that in boulder bed rivers, the energy lost in the contact zone between the water flow and the river bed is accentuated by the differences in pressure that exist around large particles. According to these authors, flow resistance should increase as the size of the large particles increases. Conversely, it should decrease when the size of the grains leads to infinitesimal spaces in between. Gintz et al. (1996) also showed that hydraulic jumps and supercritical flow, created by large particles or by steps, increase the roughness and decrease the efficiency and rate of sediment transport. However, they add that a large range of particle sizes makes sediment transport a more complex process and reduces mobility differences between the large and the small particles in the bed. Wohl (2000) arrived at the same conclusion and observed that the grain resistance tends to be weaker as the river depth increases and as the part of the contact layer in the whole water column decreases. More recently, both field and flume measurements have shown that the slope, bedforms, channel and bedload characteristics tend to increase the grain resistance of mountainous streams (Lamb et al., 2008; Comiti et al., 2009; Recking, 2009).

Twenty years ago, Williams (1983) suggested that there is not a unique threshold of sediment motion and proposed a range within which sediment transport could occur. He then considered the critical threshold as the minimum limit from which the transport of a particle of a given size could occur. Petit et al. (2005) used empirical analysis of several Belgian gravel bed rivers and linked critical specific stream power to the bedforms by studying small, medium and large rivers separately. They suggested that critical stream power $\left(\omega_{\mathrm{ci}}\right)$ increases as the size of the river decreases due to the greater bedform resistance that uses up a significant amount of energy to the detriment of that available to mobilize the bedload. Ferguson (2005) discussed their analysis and suggested from theoretical analysis of Bagnold's equation (1980) that critical specific stream power is only influenced by overall channel properties: slope and bed grain size. He replaced the depth term in Bagnold's equation by a channel slope term, and added a relative grain size term. He argues that critical stream power depends on overall channel properties and not on the details of within-channel flow. Since then, Lamb et al. (2008) have shown that thresholds for bed load transport vary significantly from one river to another depending on the slope, bed material sorting and variations in flow structure.

Relationships like Equation 1 are based on the theory of selective sediment transport which states that the initiation of movement of a boulder of a given size should correspond to a defined amount of energy. However the differing sediments and bed characteristics of natural rivers mean that this amount of energy varies, as some of the energy may be consumed by the roughness of the channel, the bed and the bedforms (Chin, 1998; Wohl, 2000). Initiation of sediment motion is indeed highly controlled by relative grain size $\left(D_{i} / D_{b}\right)$ which is usually defined as the relationship between the transported particles $\left(D_{\mathrm{i}}\right)$ and the median diameter of the particles that make up the river bed $\left(D_{b}=D_{50}\right)$ (Andrews, 1983; Ferguson et al., 1989; Knighton, 1998; Bravard and Petit, 1997; Ferguson, 2005; Mao et al., 2008). The $D_{i} / D_{b}$ ratio reveals the importance of the protrusion and hiding effect created by the presence of large particles that may protect smaller ones or be more exposed to the flow. The mobility of particles follows a power law of the relative size of the transported particles which may be expressed as follows, if the Shields parameter $\left(\theta_{\mathrm{c}}\right)$ is considered:

$$
\theta_{\mathrm{ci}}=x\left(D_{\mathrm{i}} / D_{50}\right)^{y}
$$

with

$$
\theta_{c i}=\frac{\tau_{c i}}{\left(\rho_{s}-\rho\right) g D_{i}}
$$

with $\tau_{\text {ci }}$ the shear stress needed for mobilization of a particle i and $\rho_{\mathrm{s}}$ the solid density (in $\mathrm{kg} / \mathrm{m}^{3}$ ). The value of $D_{\mathrm{i}}$ is expressed in metres in Equation 5 and in millimetres in the other equations. In Equation 4, the coefficient $x$ corresponds to the dimensionless shear stress for the reference grain size $D_{50}$ and the exponent $y$ varies from zero (fully size-selective entrainment) to -1 (complete equimobility conditions) with an average value of about -0.6 (Parker et al., 1982; Robert, 2003; Lenzi et al., 2006; Vericat and Batalla, 2007). Most observations in natural rivers show some degree of selective entrainment (Robert, 2003). According to Equation 4, as the particle size $\left(D_{\mathrm{i}}\right)$ within a bed of a given $D_{50}$ increases, the Shields parameter required to move that particle decreases. Empirical studies have shown that the coefficient $x$ (in Equation 4) is generally close to a value of $0 \cdot 045(0 \cdot 03-0 \cdot 06)$, which corresponds with the expected value of $\theta_{\mathrm{ci}}$ for uniform beds (Buffington and Montgomery, 1997; Robert, 2003; Ferguson, 2005; Mao et al., 2008).

This study aims to further investigate the relationships between sediment size and critical specific stream power and to determine the sediment transport potential of four French Mediterranean mountainous rivers: the upper Ardeche, the upper Loire, the Fango (Corsica) and the Vecchio (Corsica). The role played by relative grain size on sediment transport is investigated and related to excess stream power (i.e. total stream power minus critical stream power). The role of excess stream power on sediment sorting is also examined. Lichenometry is applied to estimate transport conditions to overcome the difficulties encountered in such energetic environments. Indeed, in boulder bed rivers, traditional tracing techniques used to determine sediment transport are less relevant and observations during flood events are impractical. In contrast, lichenometry is conducted at low stage and provides information about past events that cannot be yielded from radio-emitting or coloured tracings. Using this technique, it is possible to study a large number of flood events over a period of at least 200 years.

\section{Field sites}

We worked on four rivers in the south of France (Figure 1): two in the southern part of the Massif Central (the upper Loire and the upper Ardeche) and two in Corsica (the Fango and the Vecchio). The areas studied are in mountainous or upland regions and the drainage basins of the rivers chosen are exposed to a Mediterranean or peri-Mediterranean climate. Generally, the substratum is crystalline and metamorphic with a predominance of granite and gneiss. All four streams are alluvial rivers in steep sided valleys. Along the longitudinal profile of the Ardeche and the Vecchio, a progressive and rather regular widening of the valley may be observed. In the Loire and in the Fango catchments, the width variation is not regular. The rivers flow alternately through narrow gorges, sometimes with bedrock outcrops and small sedimentary basins. All reaches studied are riffle-pools except the steepest reaches from Corsica where the bed fall between cascades and step-pool in Montgomery and Buffington's (1997) classification. All four streams are boulder bed rivers with particles larger than $1 \mathrm{~m}$ (Table I). The reaches of the Ardeche analysed have a mean slope of $0.02 \mathrm{~m} / \mathrm{m}$, a mean bankfull width of 


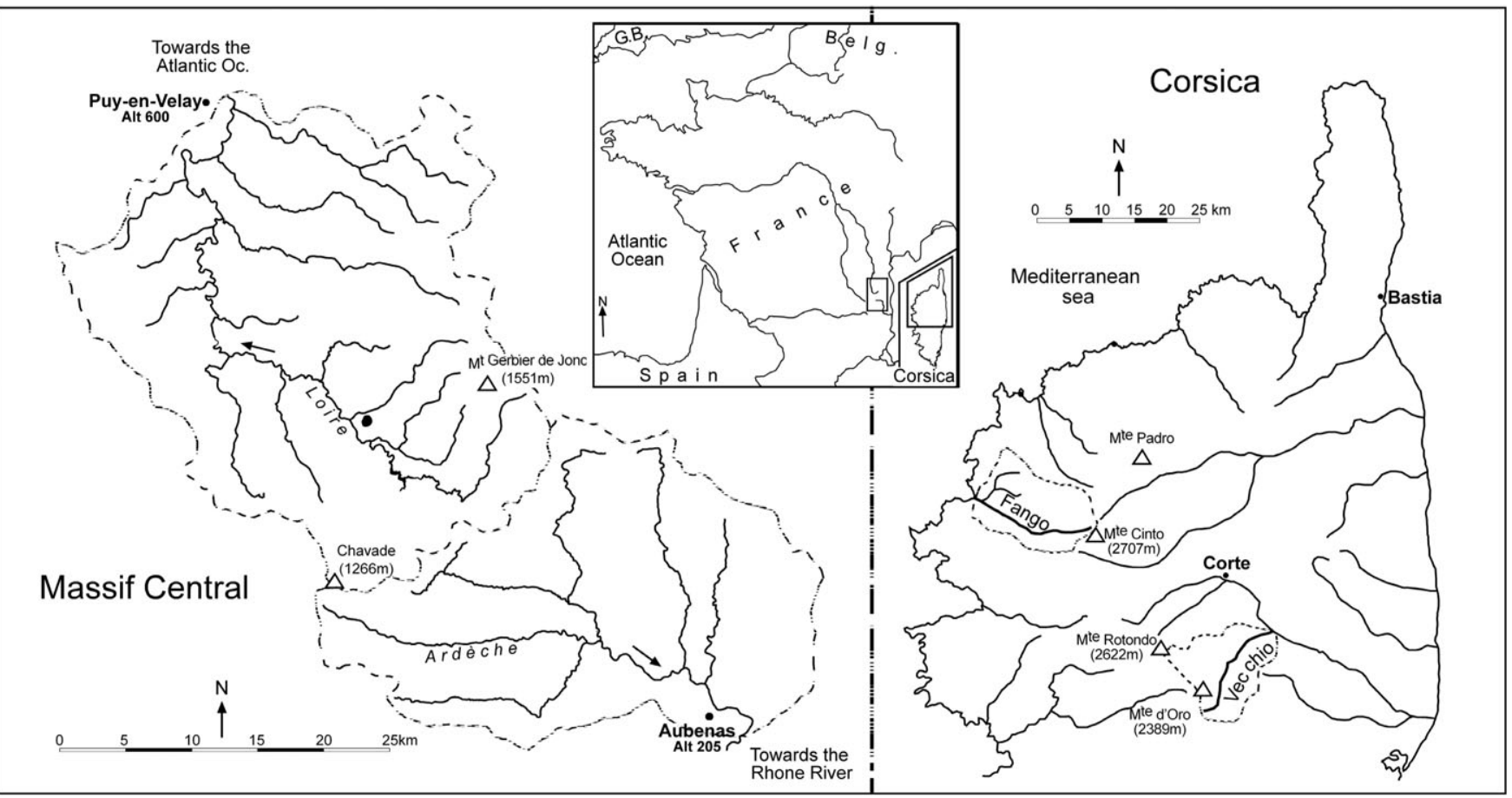

Figure 1. Location of the Ardeche and Loire in the Massif Central and the Fango and Vecchio in Corsica.

Table I. Geomorphological, sedimentological and hydrological characteristics of the studied rivers

\begin{tabular}{|c|c|c|c|c|c|c|}
\hline & $\begin{array}{c}\text { Slope } \\
\text { (minimum-maximum) } \\
(\mathrm{m} / \mathrm{m})\end{array}$ & $\begin{array}{l}\text { Catchment } \\
\text { area }\left(\mathrm{km}^{2}\right)\end{array}$ & $\begin{array}{c}\text { Ten largest blocks } \\
\text { (maximum-minimum) } \\
(\mathrm{mm})\end{array}$ & $\begin{array}{l}\text { Maximum } \\
\text { discharge } \\
\text { known }\left(\mathrm{m}^{3} / \mathrm{s}\right)\end{array}$ & $\begin{array}{c}\text { Maximum } \\
\text { stream power } \\
\left(\mathrm{W} / \mathrm{m}^{2}\right)^{\mathrm{a}}\end{array}$ & Reference \\
\hline Ardèche & $0.013-0.025$ & 470 & $1590-400$ & 1660 & 2000 & \\
\hline Loire & $0.004-0.009$ & 880 & $1160-315$ & 2000 & 3700 & \\
\hline Fango & $0 \cdot 014-0 \cdot 023$ & 235 & $1835-275$ & 900 & 9300 & \\
\hline Vecchio & $0 \cdot 008-0.025$ & 237 & $3630-$ & 731 & 6700 & \\
\hline Chassezac & 0.014 & 507 & $2920-230$ & - & - & Jacob et al., 2006 \\
\hline Figarella & $0 \cdot 036-0 \cdot 08$ & 133 & $4540-285$ & - & - & Gob et al., 2003 \\
\hline Rio Cordon & $0 \cdot 136$ & 5 & $451^{\mathrm{b}}$ & & & Lenzi et al., 2006 \\
\hline Tres Arroyos & 0.076 & 5.93 & $356^{\mathrm{b}}$ & & & Mao et al., 2008 \\
\hline
\end{tabular}

${ }^{a}$ Maximum stream power calculated for the strongest flood events over the last 50 years.

${ }^{\mathrm{b}} D_{90}$.

$43 \mathrm{~m}$ and a mean $D_{50}$ of $205 \mathrm{~mm}$. The Loire is larger $(58 \mathrm{~m})$, has a gentler mean slope $(0.006 \mathrm{~m} / \mathrm{m})$ and has a smaller mean $D_{50}(170 \mathrm{~mm})$. In Corsica, both rivers are steeper and narrower. The Fango has a mean slope of $0.02 \mathrm{~m} / \mathrm{m}$, a width of $43 \mathrm{~m}$ and a mean $D_{50}$ of $260 \mathrm{~mm}$. The Vecchio has a mean slope of $0.05 \mathrm{~m} / \mathrm{m}$, a mean bankfull width of $30 \mathrm{~m}$ and a mean $D_{90}$ of $2300 \mathrm{~mm}$ ( $D_{50}$ not available).

The southern part of the Massif Central and Corsica experience episodes of heavy autumnal rainfall during which hundreds of millimetres of precipitation may fall in a few hours. These episodes may last for several days (Conchon and Gauthier, 1985). Each storm episode concerns only a restricted area of no more than a few tens of squared kilometres and occurs on impermeable and steep slopes. The considerable volume of runoff generated cannot be absorbed in a short space of time and leads to the formation of powerful flood waves which propagate very rapidly downstream. In the Massif Central, we found maximum discharges of 2000 and $3500 \mathrm{~m}^{3} / \mathrm{s}$ for catchments as small as 470 and $880 \mathrm{~km}^{2}$. Meanwhile, in Corsica maximum discharges of 900 and $731 \mathrm{~m}^{3} / \mathrm{s}$ were recorded for catchments of 235 and $237 \mathrm{~km}^{2}$ (Table I). These floods are amongst the strongest in Europe and induce very high specific stream powers (Herschy, 2003). In the four rivers studied, stream powers often exceed 1000 to $2000 \mathrm{~W} / \mathrm{m}^{2}$ and can reach 3000 to $5000 \mathrm{~W} / \mathrm{m}^{2}$ (Gob, 2005).

\section{Methods}

\section{Lichenometry}

Lichenometry was first developed to study the evolution of glaciers (Innes, 1985). More recently, it has been applied in the study of river systems (Macklin et al., 1992; Maas et al., 1998; Jacob et al., 2002; Gob et al., 2003; Gob et al., 2005; Keesstra et al., 2005). Lichens are removed by abrasion when boulders are transported in riverbeds. Therefore, lichen thalli present on particles indicate that these particles have not been transported for an amount of time equal to the lichens' age. If the age of the lichens on a boulder can be determined, it is thus possible to date the last mobilization of the particle. A lichen growth curve, made from dated reference points such as tomb stones, bridges, etc., may be used to evaluate the age of lichens from their diameters. A calibration curve has to be 
drawn for each region studied and for each species considered. In this study, the species Rhizocarpon geographicum was chosen because it is largely found in the Mediterranean region and is the most popular species used in lichenometry. The three growth curves used in this study and the methodology of their construction are detailed in Jacob et al. (2002) and Gob et al. (2008).

The traditional lichenometric technique is based on the measurement of the diameter of the largest or the five largest thalli present on a particle (Innes, 1985). However, it is also possible to consider the entire colony on a deposit or on part of a deposit. The size/frequency diagram of this population then gives information on the evolution of the substratum and the relative age of the colony, and allows abnormal thalli to be identified. The size distribution of a single population follows an exponential law or more generally a Poisson Law (Smirnova and Nikonov, 1990; Winchester and Chaujar, 2002), whereas multimodal distributions indicate several populations in the lichen sample. Each mode in the distribution corresponds to a new supply of sediment colonized by a new generation of lichens. Bull and Brandon (1998) and Winchester and Chaujar (2002) have used this property to identify earthquake events in New Zealand and landslides in Wales, respectively.

In this study, the methodologies applied by Bull and Brandon (1998) and Winchester and Chaujar (2002) were modified to suit the characteristics of boulder bed rivers. In fluvial environments, each boulder has to be considered independently, therefore the area colonized and the numbers of thalli considered are much smaller than, for instance, on a moraine. We measured the five largest thalli on each block and calculated the average diameter [in order to avoid coalescences (Innes, 1985)]. A size/frequency diagram was constructed for each river studied. The width of the class size was determined by trial and error as proposed by Winchester and Chaujar (2002) and $1 \mathrm{~mm}$ wide classes were finally selected. The diagrams allowed us both to identify the principal morphogenetic flood events of the different rivers and to validate the technique. Each mode on the diagrams was dated using the growth curves; it was then possible to compare the diagrams with the flood record in order to ascertain whether a correlation existed between the flood events and the lichen populations. Such a correlation makes it possible to determine which flood was responsible for the last transportation of each particle colonized by Rhizocarpon. All lichens discussed in this paper were measured in the riverbed. Those from the floodplain were not considered here [they were used to date river incision (Gob et al., 2008)].

\section{Discharge and critical specific stream power calculation}

Widths provided in the text and used in the equations correspond to the mean of the bankfull widths measured at five to 10 cross-sections. As we were studying ancient floods, it was not possible to directly or indirectly measure the widths associated with a given discharge. However as the rivers studied are rather confined, the uncertainty is small. Gob et al. (2008) have shown that the rivers achieved their present-day shape at the end of the nineteenth century. We therefore considered that the river widths had not evolved during the twentieth century. The slope was calculated using a map.

The four rivers studied are equipped with gauging stations which gave the maximum discharges of flood events: four on the upper Loire, four on the Ardeche, one on the Fango and one on the Vecchio (Table II). The recurrence intervals of the floods were extrapolated from the data provided by the French Ministry of Ecology (DREAL Rhône-Alpes, DREAL Centre/ Bassin Loire-Bretagne and DREAL Corse).

In order to increase the size of the data set, measurements were made not only at the locations of the gauging stations but throughout the entire course upstream from the stations. Therefore, discharges had to be extrapolated using an equation for modest-sized basins, based on the area of the drainage basin (Bravard and Petit, 1997):

$$
q=Q(a / A)^{c}
$$

where $q$ is the discharge sought, $Q$ the discharge measured at the station (in $\mathrm{m}^{3} / \mathrm{s}$ ), a the area of the basin upstream from the sector studied (in $\mathrm{km}^{2}$ ), $A$ the area at the station $\left(\right.$ in $\mathrm{km}^{2}$ ) and $c$ a coefficient allowing the catchment's characteristics to be considered. In the studied region, most of the floods result from storm episodes concerning only a very restricted area that may affect only part of the catchment. Therefore, the $c$ coefficient had to be adjusted for each flood event. On the Loire and Ardeche two consecutive gauging stations were

Table II. Gauging stations present on the rivers studied and discharges of the floods of 2, 10 and 50-year flood

\begin{tabular}{|c|c|c|c|c|c|c|}
\hline & $\begin{array}{l}\text { Length of } \\
\text { data series }\end{array}$ & $\begin{array}{l}\text { Catchment } \\
\text { area }\left(\mathrm{km}^{2}\right)\end{array}$ & $\begin{array}{c}Q_{2} \\
\left(\mathrm{~m}^{3} / \mathrm{s}\right)\end{array}$ & $\begin{array}{c}Q_{10} \\
\left(\mathrm{~m}^{3} / \mathrm{s}\right)\end{array}$ & $\begin{array}{c}Q_{50} \\
\left(\mathrm{~m}^{3} / \mathrm{s}\right)\end{array}$ & $\begin{array}{l}Q_{\max } \\
\left(\mathrm{m}^{3} / \mathrm{s}\right)\end{array}$ \\
\hline \multicolumn{7}{|l|}{ Ardeche } \\
\hline Pt Barutel & 1986-2005 & 102 & 160 & 300 & 380 & 360 \\
\hline Pt Rolandy & 1965-1977 & 160 & 220 & 340 & - & 411 \\
\hline Pt Labeaume & 1965-2005 & 280 & 410 & 730 & 1000 & 1660 \\
\hline \multicolumn{7}{|l|}{ Loire } \\
\hline Goudet & 1946-2005 & 432 & 180 & 400 & 620 & 1600 \\
\hline Brives-Charensac & 1956-1996 & 867 & 230 & 490 & 710 & 2000 \\
\hline Bas-en-Basset & 1919-2005 & 3234 & 580 & 1200 & 1800 & 3500 \\
\hline \multicolumn{7}{|l|}{ Fango } \\
\hline Galéria & 1976-2005 & 129 & 94 & 170 & 230 & 900 \\
\hline \multicolumn{7}{|l|}{ Vecchio } \\
\hline Venaco & 1959-2005 & 147 & 180 & 340 & 460 & 731 \\
\hline
\end{tabular}

Note: $Q_{\max }$ is the maximum discharge ever observed at the gauging station. Data is provided by the French Ministry of Ecology (DREAL Rhône-Alpes, DREAL Centre/Bassin Loire-Bretagne and DREAL Corse) 
used to calculate, using trial and error, the c coefficient that best estimated the downstream discharge evolution. The values of $c$ range between 0.4 and 1 . In Corsica where only one gauging station was available on each river the value of one was considered.

In order to determine the entrainment threshold using lichenometry we followed the approach adopted by Andrews (1983): the biggest particle moved in a particular flow is assumed to define the threshold flow strength for that grain size, provided that other larger particles present in the bed are not mobilized by this discharge. In order to associate a given flow with the largest block that the river may transport, envelop curves which pass to the right and underneath the data points in the graph illustrating critical stream power and transported grain size were used. Indeed, Costa (1983) has shown that envelop curves yield better results than regression lines. Since the excess stream power (total stream power minus critical stream power) may be very high during large floods, particle mobilization thresholds were calculated for the most common events. Particles that had not been mobilized (with older lichens), larger than $D_{\mathrm{i}}$, were present within the bed in most reaches. Unfortunately in some cases $D_{i}$ was the largest particle. In these cases the sediment motion threshold may be overestimated as, had larger particles been present, they too could have been mobilized. However this overestimation may be considered minimal as lichenometry permits a large number of flood events (low and high) to be examined and as envelop curves were used.

\section{Determining sediment size}

Sediment sizes distributions were determined on each site where lichen sizes were measured using Wolman's (1954) technique. This technique allowed the calculation of the $D_{50}$ and $D_{90}$ at many points along the longitudinal profile. However, at some points, to characterize the coarsest fraction of the sediment distribution, the average of the 10 largest particles on the bar $\left(D_{10+}\right)$ was used rather than the $D_{90}$. This was necessary in cases where it was not possible, either due to the availability of sediment particles or due to time constraints, to measure 100 particles.

\section{Results and Discussions}

\section{Lichenometry}

Size/frequency diagrams were used to construct a table in which each lichen size is related to the corresponding flood event (Table III). Table III was then used to determine which flood was responsible for the transport of every particle on which lichens were found. When several floods occurred in a very short period of time (several events in the same year or within a few years), it was not possible to distinguish between the morphogenetic floods. In these cases, we always considered the strongest event in order not to underestimate the critical discharge. Size frequency diagrams of lichens in the four rivers are presented in Figure 2 along with discharges for the related flood events.

The size frequency distribution for the Loire (Figure 2A) is clearly multimodal, showing the presence of several lichen populations. Four peak frequencies are well defined within the range of 1 and $21 \mathrm{~mm}$ and there is a tail between the range of 21 and $41 \mathrm{~mm}$ in which peaks are very weak. In this river, lichens on boulders in the active channel are less than 80 years old. This shows that all of the particles in the Loire can
Table III. Summary of correspondences between lichen size and flood events for the four studied rivers. Flood discharges are given at different gauging stations $(A, B$ and $C)$

\begin{tabular}{|c|c|c|c|c|c|}
\hline & \multirow{2}{*}{$\begin{array}{l}\text { Lichen size } \\
(\mathrm{mm})\end{array}$} & \multirow{2}{*}{$\begin{array}{l}\text { Flood } \\
\text { event }\end{array}$} & \multicolumn{3}{|c|}{ Discharge $\left(\mathrm{m}^{3} / \mathrm{s}\right)$} \\
\hline & & & A & B & $\mathrm{C}$ \\
\hline Loire & 0 & 2001 & 688 & - & 1010 \\
\hline $\mathrm{A}=432 \mathrm{~km}^{2}$ & 5 & 1996 & 533 & - & 2170 \\
\hline $\mathrm{B}=867 \mathrm{~km}^{2}$ & 6 & 1994 & - & 650 & 1030 \\
\hline \multirow[t]{6}{*}{$\mathrm{C}=3234 \mathrm{~km}^{2}$} & & 1993 & 407 & - & - \\
\hline & $9-11$ & 1980 & 1660 & 2000 & 3500 \\
\hline & $14-16$ & 1976 & - & 835 & 1760 \\
\hline & & 1973 & 345 & & - \\
\hline & $19-21$ & 1968 & 310 & 535 & 705 \\
\hline & 31 & 1943 & - & - & - \\
\hline Ardeche & 0 & 2001 & 264 & - & 548 \\
\hline$A=102 \mathrm{~km}^{2}$ & $1-3$ & 1997 & 360 & - & 590 \\
\hline $\mathrm{B}=160 \mathrm{~km}^{2}$ & 4 & 1992 & 289 & - & 1660 \\
\hline \multirow[t]{4}{*}{$\mathrm{C}=280 \mathrm{~km}^{2}$} & $5-7$ & 1982 & - & 508 & 758 \\
\hline & 8-1 & 1977 & - & - & 625 \\
\hline & $11-12$ & 1970 & - & 363 & 600 \\
\hline & $14-16$ & 1958 & - & - & 1172 \\
\hline Fango & 0 & 1999 & 184 & - & - \\
\hline \multirow[t]{5}{*}{$\mathrm{A}=129 \mathrm{~km}^{2}$} & $0 \cdot 1-0 \cdot 2$ & 1997 & 244 & - & - \\
\hline & $0 \cdot 3$ & 1994 & 176 & - & - \\
\hline & $0 \cdot 4-0 \cdot 5$ & 1992 & 900 & - & - \\
\hline & $0 \cdot 6-0 \cdot 7$ & 1979 & 161 & - & - \\
\hline & $1-1 \cdot 1$ & 1968 & - & - & - \\
\hline & $0 \cdot 3-0 \cdot 4$ & 1992 & 266 & - & - \\
\hline \multirow[t]{4}{*}{$\mathrm{A}=147 \mathrm{~km}^{2}$} & $0 \cdot 5-0.6$ & 1981 & 198 & - & - \\
\hline & $0 \cdot 7-0 \cdot 8$ & 1976 & 731 & - & - \\
\hline & $0 \cdot 9-1 \cdot 1$ & 1973 & 637 & - & - \\
\hline & $1 \cdot 4-1 \cdot 6$ & 1960 & 450 & - & - \\
\hline
\end{tabular}

be considered as bedload, and that sediment transport occurs quite frequently.

In Figure 2(A), the youngest populations of lichens show that four flood events were highly morphogenetic. Each peak corresponds well with the flood series. The 19 to $21 \mathrm{~mm}$ lichens correspond to the 1963, 1965 and 1968 events and the 14 to $16 \mathrm{~mm}$ lichens to the 1973 and 1976 events. The 1980 flood, which has a recurrence interval of several hundred years, is well marked in the size frequency diagram $(9-11 \mathrm{~mm})$ but with a slight shift towards the younger lichens. The fourth peak, between 5 and $6 \mathrm{~mm}$, corresponds to the 1994 and the 1996 events. The 1980 event had an exceptional magnitude explaining the height of the peak at around $10 \mathrm{~mm}$ and the small amount of thalli larger than $11 \mathrm{~mm}$. This flood would have mobilized most of the particles present in the bed and therefore would have almost completely destroyed the previous populations of lichens. Finally, it should be highlighted that a flood with a recurrence interval of at least 100 years occurred in 2001. However, as lichens require about five years to colonize bare substratum in this type of environment, the lichens associated with this flood were undetectable at the time the survey campaigns were undertaken.

The lichen distribution for the Ardeche (Figure 2B) is also multimodal showing several lichen populations. There are two well formed peaks between 0 and $12 \mathrm{~mm}$ and several smaller peaks between 13 and $55 \mathrm{~mm}$. For the second half of the twentieth century, three size ranges are predominant in the riverbed of the Ardeche (Table III): $15 \mathrm{~mm}$ (1958), $9 \mathrm{~mm}$ (1977) and $6 \mathrm{~mm}$ (1982). The highest peak (5-7 mm) on Figure 2(B) does not correspond to the strongest flood known in the catchment (1992). This can be explained by the fact 


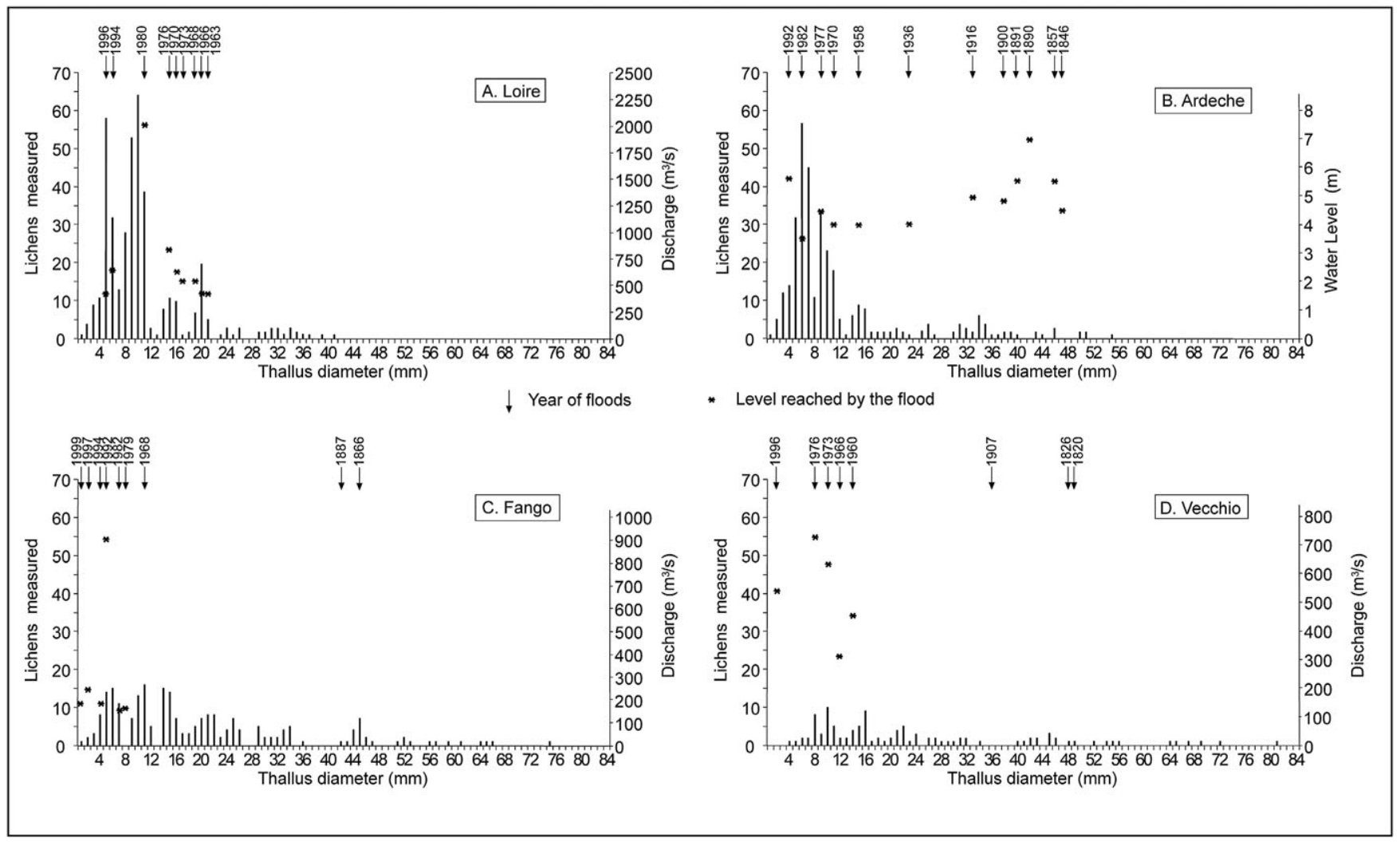

Figure 2. Size/frequency diagrams of the lichen populations in the riverbeds of the four rivers studied. Each high frequency peak corresponds to a morphogenetic flood event. The water levels or discharges of these events are indicated on the right axis and their date may be seen on top of the graphs. In order to have a longer flood series, the water levels on the right axis of (B) do not refer to the gauging station directly downstream from the studied catchment. Instead, they refer to a gauging station which is more well-documented, several kilometres downstream (Ucel, catchment area $=480 \mathrm{~km}^{2}$ ).

that $82 \%$ of the measured lichens were surveyed in the upper part of the basin, upstream from the gauging station. In this part of the basin, the strongest flood occurred in 1982, with a discharge estimated at $508 \mathrm{~m}^{3} / \mathrm{s}$ (recurrence interval of approximately 500 years) (see Table III). The 1992 event was not exceptional at this particular place. Meanwhile, at the gauging station, which is located downstream of a tributary, the flood was the strongest since 1890. Another remarkable element is the high frequency of large events at the end of the nineteenth century (i.e. that correspond to the end of the Little Ice Age). Despite the high number of flood events, nineteenth century lichen populations are not very large and the correlation between size/frequency peaks and floods is not certain. This is because lichens over 100 years old have a very slow lichen growth rate, and therefore may be dated with less precision (1 mm corresponding to a range of several years for lichens older than 100 years). In addition, remobilization of particles in subsequent floods leads to a poor archive of older events. Particles with old lichens present are rare and are located in marginal positions or behind vegetal or rocky shelter, where they are less likely to be remobilized.

Figures 2(C) and 2(D) show data obtained from the two Corsican streams. Information on discharges is rather limited and fewer field observations were undertaken in Corsica. Due to the limited amount of data, the peaks are relatively weak and it was therefore not possible to associate an individual flood event with each peak. In light of this, the maximum event corresponding to the range of thalli sizes of each peak was considered (Table III). Only four peaks were considered on the Fango River (between 1968 and 1997) and only five peaks on the Vecchio River (between 1960 and 1992).
From Table III it was possible to calculate the critical specific stream power relationship for each river studied. Although hundreds of particles were measured, only the largest particles measured for each site and for each flood event were used to build the curve; the transport thresholds for the four rivers were finally determined from 136 points (Figure 3 ).

\section{Critical stream power}

In Figure 3, one may see that the pattern of data is not the same on all four graphs. Their vertical distribution depends on the river's characteristics and whether strong flood events had taken place (e.g. Figure 3C, on the Fango two data populations are evident). However, Table I demonstrates that all four rivers have experienced very high stream powers, rarely observed in such small catchments. This high energy is due to their confined morphology associated with very large discharges and steep slopes. The relationships in Figure 3 define the critical thresholds of sediment transport and allow the mobility thresholds of the coarsest particles of the studied rivers to be determined. The analysis of critical specific stream power and sediment size shows that all four rivers display a high potential rate of bed load transport. Even the weakest flood events transport most of the particles in the bed (at least up to the $D_{50}$ ). However, these common events are not able to move the largest particles everywhere on the longitudinal profile of the four rivers (such as in the Ardeche and the Fango). When discharge increases, the whole load is mobilized in three out of the four rivers. In the Vecchio, the largest particles are much 

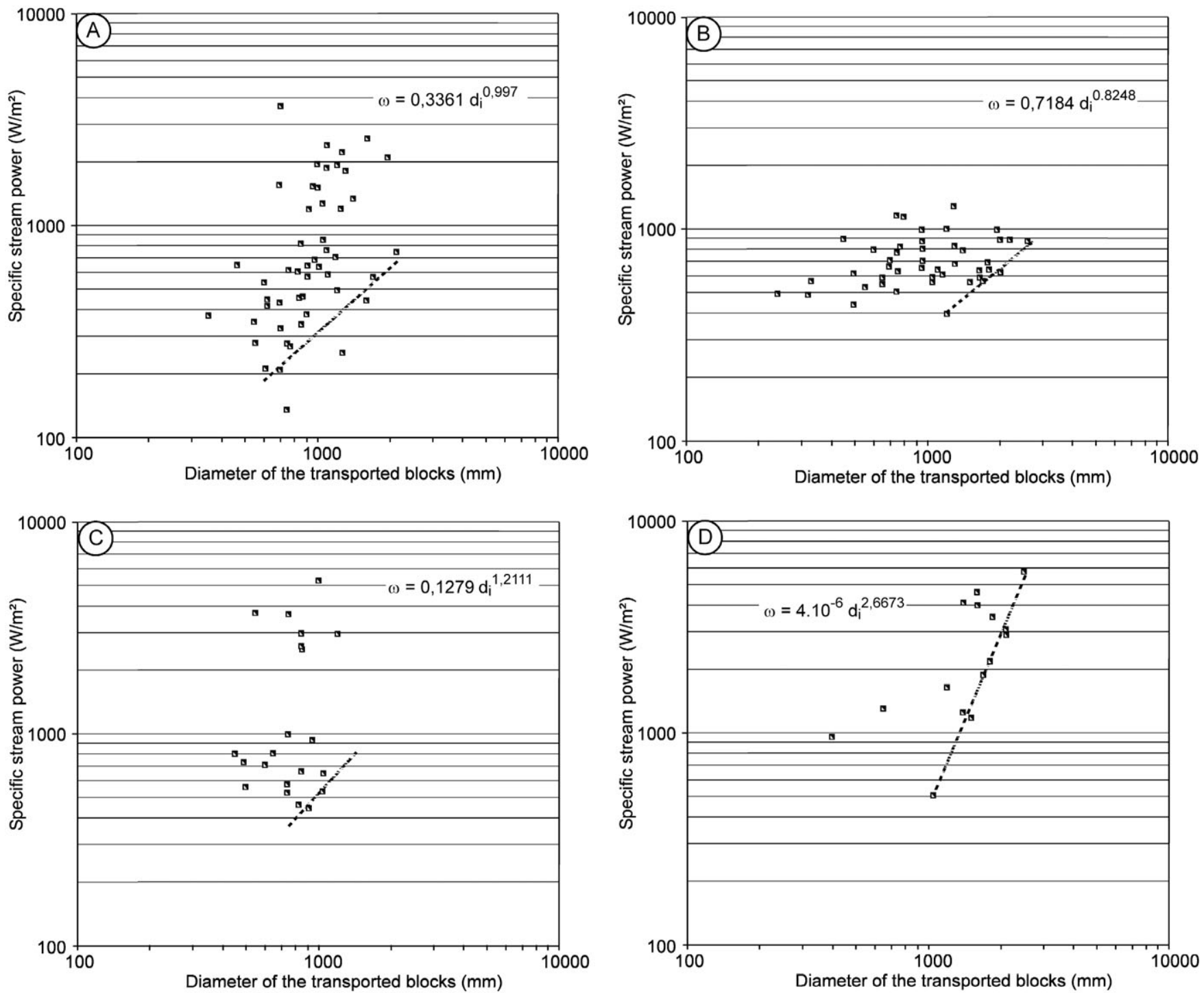

Figure 3. Relationship between the critical stream power and the diameter of mobilized particles in (A) the Upper Loir, (B) the Ardeche, (C) the Fango and (D) the Vecchio.

larger than in the other rivers, and they remain in place even during exceptional events. Indeed, despite very high stream powers, 3 to $4 \mathrm{~m}$ wide particles are not mobilized.

By comparing the relationships derived from this study to those in the literature (Costa, 1983; Williams, 1983; Gob et al., 2003, Jacob et al., 2006; Lenzi et al., 2006; Mao et al., 2008) (Figure 4 and Table IV) one can see that the criteria for particle motion may be quite different from one river to the next, even for the same types of rivers (boulder and block rivers). In Figure 4, the curves are distributed over a wide range of specific stream powers. To carry a particle of a given size, the Chassezac River (Jacob et al., 2006) requires a specific stream power nearly 10 times higher than that needed in the upper Loire. The positions of the curves suggest, however, that groupings may be made. As already proposed by Jacob et al. (2006), the Chassezac River and the Figarella River may be grouped as they seem to be subject to the same constraints. Then, even if slightly less evident, a second group may include the Ardeche, the upper Loire and the Fango. The Vecchio corresponds rather well with Williams's (1983) and Costa's (1983) envelop curves but it cannot be placed in any of the two previous groups.

Using data presented in Lenzi et al. (2006) and Mao et al. (2008) it was possible to construct the same kinds of curves for two small streams in the Italian Alps (Rio Cordon) and in the Chilean Andes (Tres Arroyos). The Rio Cordon is much smaller than the other rivers presented in this study, with an average width of $5.7 \mathrm{~m}$, a mean slope of $13.6 \%$, a basin area of $5 \mathrm{~km}^{2}$, a mean $D_{50}$ of $119 \mathrm{~mm}$ and a mean $D_{84}$ of $357 \mathrm{~mm}$. The Tres Arroyos has a mean slope of $7.6 \%$, a basin area of $5.93 \mathrm{~km}^{2}$, a mean $D_{50}$ of $67 \mathrm{~mm}$ and a mean $D_{84}$ of $278 \mathrm{~mm}$. Two methods were used to obtain data from the Rio Cordon: marked particles and a sediment trap. The results obtained are quite similar and have been mixed. Lenzi's curve is at an intermediate position in Figure 4. Mao et al. (2008) used marked particles and a Helley-Smith sampler on the Tres Arroyos. Mao's curve in Figure 4 was constructed based on marked particles only. The data obtained with the sampler was not used as it only concerned small particles (gravel). Both Lenzi et al. (2006) and Mao et al. (2008) used the best-fitting curve instead of the envelop curve. However in this study we constructed envelop curves for Lenzi and Mao's data. In Lenzi's relationship, the envelop curve is quite close to the best-fitting curve. However, for Mao's data, the two curves are quite different. Mao's envelop curve is very similar to those of the Figarella and Chassezac. In the rest of the paper, these two envelop curves will be used to compare data obtained using similar methodologies. 


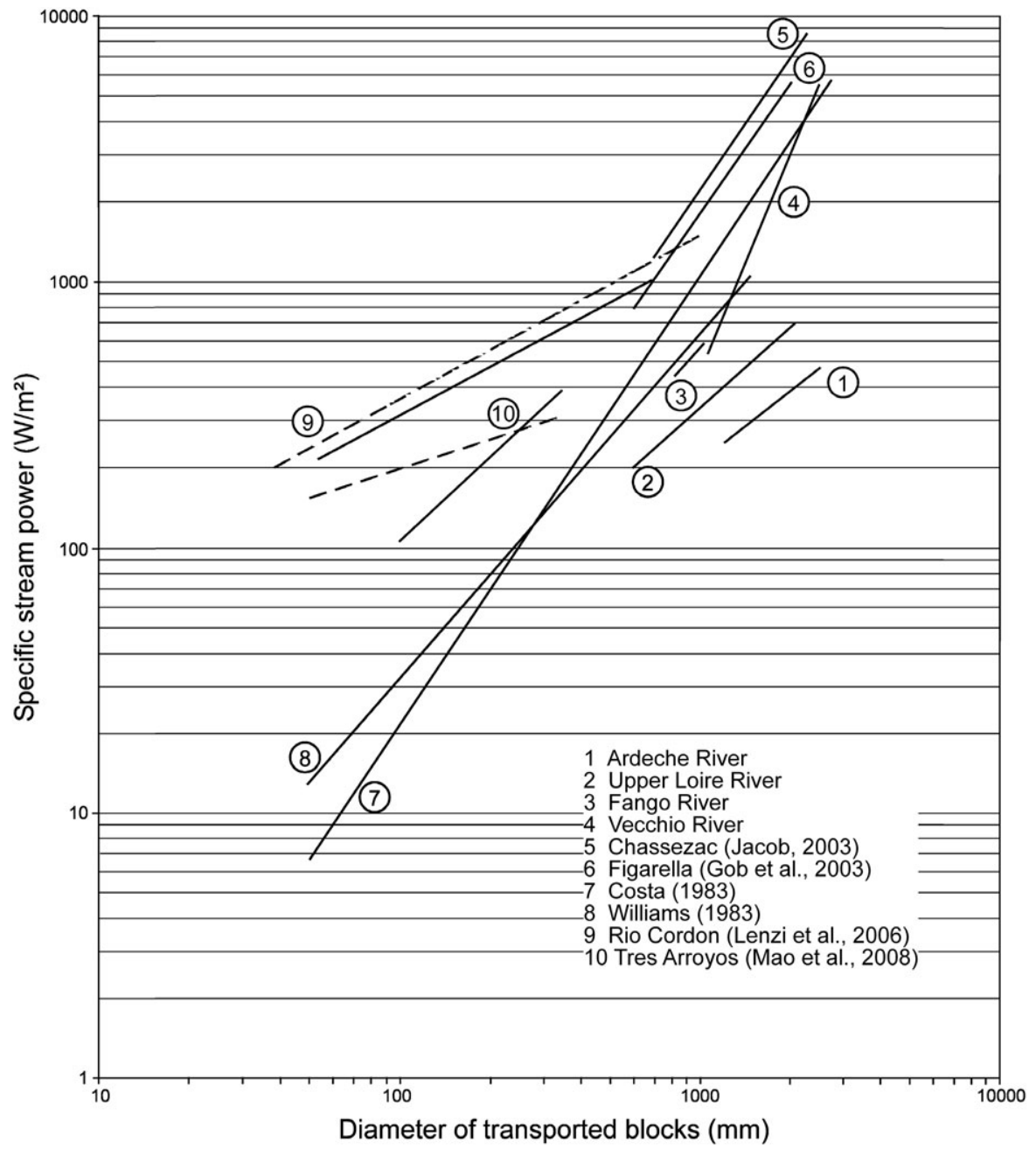

Figure 4. Relationship between the critical stream power and the diameter of mobilized particles in several mountainous boulder bed rivers. Curves 7 and 8 gather data sets from several catchments with different characteristics. The eight other curves concern only one river. The dashed lines in curves 9 and 10 represent the best-fitting curves and the unbroken lines represent the envelop curves.

Table IV. Summary of equations in Figure 4

\begin{tabular}{|c|c|c|c|c|c|}
\hline & Rivers & Equation & Range of $D_{\mathrm{i}}(\mathrm{mm})$ & Range of $D_{10+}(\mathrm{mm})^{\mathrm{b}}$ & Reference \\
\hline 1 & Ardeche $^{\mathrm{a}}$ & $\omega_{\mathrm{c}}=0.7184 d_{\mathrm{i}}^{0.8248}$ & $1200-2600$ & $490-1590$ & \\
\hline 2 & Upper Loire ${ }^{a}$ & $\omega_{\mathrm{c}}=0.3361 d_{\mathrm{i}}^{0.997}$ & $750-2100$ & $550-1150$ & \\
\hline 3 & Fango $^{a}$ & $\omega_{\mathrm{c}}=0.1279 d_{\mathrm{i}}^{1.2111}$ & $900-1050$ & $950-1190$ & \\
\hline 4 & Vecchio $^{a}$ & $\omega_{\mathrm{c}}=4 \times 10^{-6} d_{\mathrm{i}}^{2.6673}$ & $1050-2500$ & $510-5800$ & \\
\hline 5 & Chassezac $^{a}$ & $\omega_{\mathrm{c}}=0.025 d_{\mathrm{i}}^{1.647}$ & $700-2300$ & 200-2900 & Jacob et al. (2006) \\
\hline 6 & Figarella $a^{a}$ & $\omega_{\mathrm{c}}=0.0249 d_{\mathrm{i}}^{1.619}$ & 900-2000 & $650-5500$ & Gob et al. (2003) \\
\hline 7 & Rivers of Colorado & $\omega_{\mathrm{c}}=0.009 d_{\mathrm{i}}^{1.686}$ & $50-2800$ & - & Costa (1983) \\
\hline 8 & Rivers from literature & $\omega_{\mathrm{c}}=0.079 d_{\mathrm{i}}^{1.3}$ & $10-1500$ & - & Williams (1983) \\
\hline 9 & Rio Cordon & $\omega_{c}=20.675 d_{\mathrm{i}}^{0.6188}$ & $38-1024$ & $451^{\mathrm{c}}$ & Lenzi et al. (2006) \\
\hline 10 & Rio Cordon (envelop curve) & $\omega_{\mathrm{c}}=18.756 d_{\mathrm{i}}^{0.6089}$ & $57-724$ & $451^{\mathrm{c}}$ & Lenzi et al. (2006) \\
\hline 11 & Tres Arroyos & $\omega_{\mathrm{c}}=36.095 d_{\mathrm{i}}^{0.3655}$ & $50-350$ & $356^{c}$ & Mao et al. (2008) \\
\hline 12 & Tres Arroyos (envelop curve) & $\omega_{\mathrm{c}}=0.9123 d_{\mathrm{i}}^{1.0307}$ & $100-350$ & $356^{\mathrm{c}}$ & Mao et al. (2008) \\
\hline
\end{tabular}

a Sediment motion determined using lichenometry.

${ }^{b}$ Range of $D_{10+}$ of the reaches included in the envelope curves.

${ }^{\mathrm{c}} \mathrm{D}_{90}$.

Role of relative sediment size and gradient of the channel

Coarse bed load is transported more easily in the Ardeche than in the Chassezac, and in the Vecchio than in the Figarella. In contrast to the observations of Petit et al. (2005) for Belgian rivers, the basin size does not seem to play a decisive role in the six French rivers examined in this study. Table IV shows the ranges of the 10 largest blocks measured on the beds of the reaches included in the envelop curves. The upper Loire, the upper Ardeche and the Fango have smaller particles than the Figarella, the Chassezac and the Vecchio where boulders are much larger (Jacob, 2003; Gob, 2005). Figure 4 and Table IV show that within French rivers, those with smaller blocks correspond to the lower curves on Figure 4. This suggests that the larger the riverbed particles are, the higher the energy 


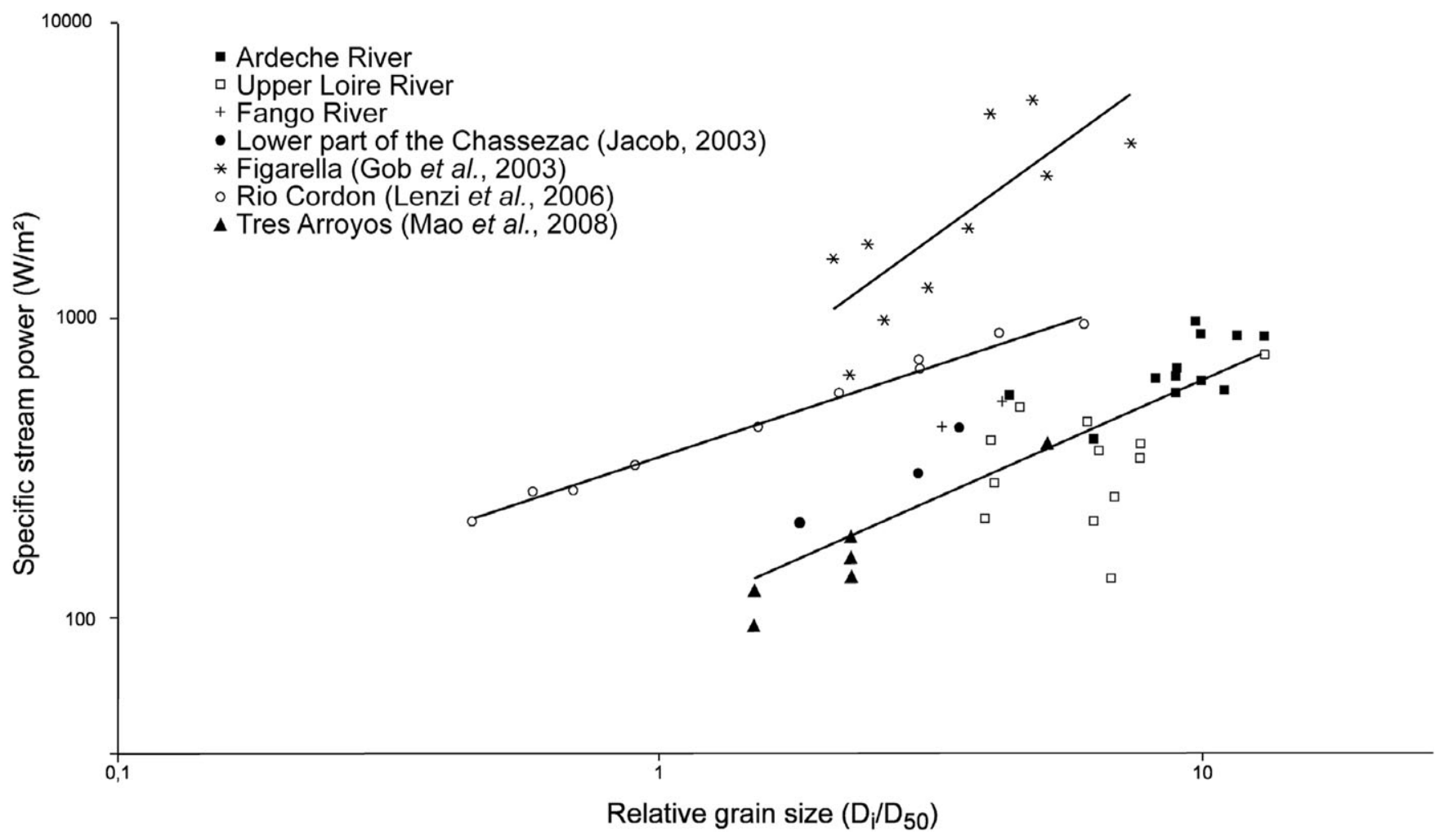

Figure 5. Relationship between the specific stream power and the relative sediment size of the transported particles, $\omega_{\mathrm{ci}}=x\left(D_{\mathrm{i}} / D_{50}\right)^{y}$.

needed to initiate sediment motion of a given particle must be. In the six French rivers the critical threshold seems to correspond well with the widespread idea that critical motion parameters (Shields criterion $\theta_{\mathrm{ci}}$ ) depend on relative grain sizes $\left(D_{\mathrm{i}} / D_{b}\right)$ : large particles may delay transport of smaller-thanaverage ones (hiding effect) and small particles may favour transport of larger-than-average ones (protrusion effect) (Knighton, 1998; Ferguson, 2005). Relationships between critical specific stream power $\left(\omega_{\mathrm{c} i}\right)$ and the relative size of the bed particles $\left(D_{i} / D_{50}\right)$ were therefore determined. Figure 5 shows the log-log relationship between the relative size $\left(D_{\mathrm{i}}\right)$ $\left.D_{50}\right)$ and the critical specific stream power $\left(\omega_{\mathrm{ci}}\right)$ in seven out of the eight rivers of Figure 4 (those with $D_{50}$ data available). Table $\mathrm{V}$ summarizes the river characteristics used in Figure 5 (different from Figure 4 because the $D_{50}$ was only available at a restricted number of sites). Concerning the Chassezac, $D_{50}$ data was available only in the lower basin, where sediments were smaller and the slope was gentler. Table VI gives the equation for the regression lines in Figure 5.

Figure 5 shows that relative size of particles alone may not explain the distribution of curves over the large range of specific stream powers in Figure 4. For a given relative grain size, the Ardeche, the Loire, the lower Chassezac and the Tres Arroyos still require a lower critical specific stream power than the Figarella and Rio Cordon. Ferguson (2005) and Lamb et al. (2008) suggest that channel slopes could account for such discrepancies. The slopes of the sites used in Figure 5 to construct the Ardeche, Loire, Fango and lower Chassezac curves range from $0 \cdot 2$ to $3 \%$. The channel slopes of the Figarella range between 4 and $8 \%$ while Mao et al. (2008) indicate a slope of $13 \cdot 6 \%$ for the Rio Cordon. Figure 5 suggests that steeper rivers require more specific stream power to move a particle of a given relative size. However, the slope of the Tres Arroyos is $7 \cdot 6 \%$, which does not correspond to this schema and thus slope and relative grain size are not the only explicative factors. Mao et al. (2008) point out that different field methodologies could be responsible for the discrepancies between the relationships. This may account for the discrepancies between the relationships of the Figarella and the Rio Cordon which both have strong channel gradients (in the Figarella lichenometry may slightly overestimate specific stream power). However, as lichenometry was used for all rivers but the Rio Cordon, we may consider that any discrepancies between the French rivers may not be due to differences in the methodologies used.

Ferguson (2005) proposes two general equations for critical stream power from a logarithmic flow resistance law (Equation 7) and from a power flow resistance law (Manning-Strickler form) (Equation 8) which give approximately the same results (Ferguson, 2005; Mao et al., 2008).

$$
\omega_{c i}=\frac{2 \cdot 3}{\kappa} \rho\left(\theta_{c b} R g D_{b}\right)^{1.5} \log \left[\frac{30 \theta_{c b} R}{e m S}\left(\frac{D_{i}}{D_{b}}\right)^{1-y}\right]\left(\frac{D_{i}}{D_{b}}\right)^{1.5(1-y)}
$$

and

$$
\omega_{c i}=a \rho\left(\theta_{c b} \operatorname{Rg} D_{b}\right)^{1 \cdot 5}\left(\frac{\theta_{c b} R}{S}\right)^{1 / 6}\left(\frac{D_{i}}{D_{b}}\right)^{5(1-y) / 3}
$$

where $\kappa$ is von Karman's constant, $R$ denotes sediment density and submerged specific gravity, $m$ is a parameter ranging from $\sim 1$ to $>10$ depending on the degree of sorting of the bed and of form roughness in the channel (in well sorted beds $m=1$ ), $y$ is the hiding and protrusion factor (see Equation 4) and a corresponds to the coefficient $a$ in the Strickler relation $[a=$ 8.2 or 6.7 according to Ferguson (2005)]. To solve the equation one may use $\kappa=0 \cdot 4, R=1 \cdot 6, \rho=1000 \mathrm{~kg} / \mathrm{m}^{3}$ and $g=$ $9 \cdot 81 \mathrm{~m} / \mathrm{s}$. The deviation of the terms $m$ and a from 1 and $8 \cdot 2$ represent the deviation from a well sorted bed (Mao et al. 2008). Ferguson (2005) suggests $\theta_{\mathrm{cb}}=0.045$ and $y=0 \cdot 6$.

Once Ferguson's relationships are applied to our data, both yield similar results but lead to an incorrect estimation of the 
Table V. Characteristics of reaches used in Figure 5

\begin{tabular}{|c|c|c|c|c|}
\hline & $\begin{array}{c}D_{50} \\
\text { (minimum-maximum) } \\
(\mathrm{mm})\end{array}$ & $\begin{array}{c}D_{\mathrm{i}} / D_{50} \\
\text { (minimum-maximum) }\end{array}$ & $\begin{array}{c}\text { Slope }(\mathrm{m} / \mathrm{m}) \\
\text { (minimum-maximum) }\end{array}$ & Reference \\
\hline Ardeche & $150-340$ & $4 \cdot 41-13 \cdot 00$ & $0 \cdot 013-0 \cdot 033$ & \\
\hline Upper Loire & $110-260$ & $4 \cdot 00-13 \cdot 13$ & $0 \cdot 0041-0 \cdot 009$ & \\
\hline Fango & $245-270$ & $3 \cdot 33-4 \cdot 29$ & $0 \cdot 014-0 \cdot 023$ & \\
\hline Lower Chassezac & $120-160$ & $1 \cdot 81-3 \cdot 56$ & $0 \cdot 0017-0 \cdot 018$ & Jacob et al. (2006) \\
\hline Rio Cordon & 119 & $0 \cdot 76-8 \cdot 61$ & $0 \cdot 136$ & Lenzi et al. (2006) \\
\hline Tres Arroyos & 67 & $1 \cdot 49-5 \cdot 22$ & $0 \cdot 076$ & Mao et al. (2008) \\
\hline
\end{tabular}

Table VI. Summary of equations in Figure 5

\begin{tabular}{lcccc}
\hline & $x$ & $y$ & $R^{2}$ & Reference \\
\hline $\begin{array}{l}\text { Ardeche } \\
\text { Upper Loire }\end{array}$ & $97 \cdot 836$ & 0.8047 & 0.62 & \\
$\begin{array}{l}\text { Fango } \\
\text { Lower Chassezac }\end{array}$ & & & & \\
$\begin{array}{l}\text { Tres Arroyos } \\
\text { Figarella }\end{array}$ & $402 \cdot 21$ & 1.3221 & 0.61 & Gob et al. (2003) \\
Rio Cordon & $344 \cdot 27$ & 0.6089 & 0.99 & Mao et al. (2008) \\
\hline
\end{tabular}

Note: $x$ and $y$ corresponds to the coefficient and the exponent of the equation $\omega_{\mathrm{ci}}=x\left(D_{\mathrm{i}} / D_{50}\right)^{y}$.

critical specific stream power. Observed stream powers are smaller than predicted in the Ardeche, Loire, Fango and lower Chassezac and higher in the Figarella. Mao et al. (2008) observed the same trends: Equations 7 and 8 underestimate critical stream power in the Rio Cordon and the Tres Arroyos. They assume that, as Ferguson (2005) demonstrated that critical stream powers are not affected by form resistance, the underestimation should be attributed to the value of the critical shear stress $\left(\theta_{\mathrm{cb}}\right)$ needed to transport the mean grain size of the bed $\left(D_{50}\right)$.

The back calculation of critical shear stress to move the bed particles using Equation 7 gives a mean $\theta_{\mathrm{cb}}$ between 0.020 and 0.026 for the Loire, Ardeche and lower Chassezac and $0 \cdot 050$ for the Figarella (considering $y=0 \cdot 7$ ). These values are consistent with streams and rivers with gentle slopes (e.g. $<0.005)$, and grain sizes that are very small in comparison to the flow depth. Mueller et al. (2005) and Recking (2009) observed a relationship between Shields criterion and channel slope. Mueller et al. (2005) constructed an empirical relationship predicting that a $\theta_{\mathrm{cb}}$ is between 0.025 and 0.035 for low gradient channels, and between 0.06 and 0.12 for steeper channels (Figure 6). Our data follow the same trends, with an increase in critical shear stress as slope increases. However the values of critical shears stress are always lower in our study, independent of the methodology applied (French or Italian rivers). The hiding factor $y$ used in Equation 8 could partially explain this discrepancy. The value of 0.7 was used. However, by increasing the hiding factor to $0 \cdot 9$, the $\theta_{\mathrm{cb}}$ ranges between 0.028 and 0.04 for low gradient rivers and 0.07 for the steeper rivers. This corresponds better with the results predicted by Mueller et al. (2005)

\section{Excess specific stream power and sediment sorting}

When one subtracts the stream power needed to mobilize the particles from the total stream power generated by the river during a flood (excess specific stream power, $\omega-\omega_{\mathrm{ci}}$ ), one may see that the four rivers studied use relatively little energy in comparison to the amount of energy available in such environments. In the Ardeche, the excess of energy after transportation of the mean of the 10 largest blocks during the strongest flood of the last century ranges from $250 \mathrm{~W} / \mathrm{m}^{2}$ to $1400 \mathrm{~W} / \mathrm{m}^{2}$; in the Loire the range of excess stream power varies between 500 and $3500 \mathrm{~W} / \mathrm{m}^{2}$ and in the Fango, the residual energy is even larger, from 1500 to $9000 \mathrm{~W} / \mathrm{m}^{2}$. However, in the Vecchio, even the exceptional 1976 flood event did not generate enough energy to transport the mean of the 10 largest blocks; the excess stream power was therefore negative at some places and varied from $-8000 \mathrm{~W} / \mathrm{m}^{2}$ to $50 \mathrm{~W} / \mathrm{m}^{2}$.

Hassan et al. (1992) and Gintz et al. (1996) showed that the excess stream power compared to the energy actually consumed for bed load mobilization governs the distance covered by the transported particles and the load progress speed. In the Ardeche it was possible to assess the role played by the residual energy on sediment sorting. Figure 7 (unbroken lines) shows the longitudinal evolution of the excess stream power after the transportation of the mean of the 10 largest blocks in the Ardeche for the 1958, 1982 and the $Q_{2}$ flood events (10, 500 and 2 years recurrence intervals, respectively). The excess energy is not constant along the longitudinal profile: it is very high in the head watershed, then rapidly decreases in the middle reach of the course and increases again in the lower part of the studied basin. The rapid increase of energy after the 19th kilometre is due to a narrowing of the valley caused by a $50 \mathrm{~m}$ thick lava flow that closed $3 \mathrm{~km}$ of the valley during the Pleistocene.

Figure 7 also shows the longitudinal distribution of the size frequency of the Ardeche's largest particles (dashed lines). The average of the 10 largest blocks was measured regularly along the river profile. A distinction was made between the two types of rock found in the riverbed: basalt and granite. The general appearance of the curve is typical of those found in the literature showing classical downstream fining (Ferguson et al., 1996). Between the 25th and the 30th kilometre the sediment size increases because of a sediment injection from a long outcrop of basalt and from two large tributaries. In order to evaluate the efficiency of sediment sorting, we followed the approach employed by Werritty (1992). The curves were divided into three sectors (there were only two in Werrity's study because the second sector corresponding to sediment injection was absent). The first and the third sectors correspond to those presented by Werritty (1992). According to Werritty, rapid fining is caused by a combination of hydraulic sorting and attrition and gradual fining is caused by attrition only. If the coefficient of reduction of the curve in the third sector is subtracted from the coefficient of reduction of the curve in first sector the level of hydraulic sorting may be calculated. 


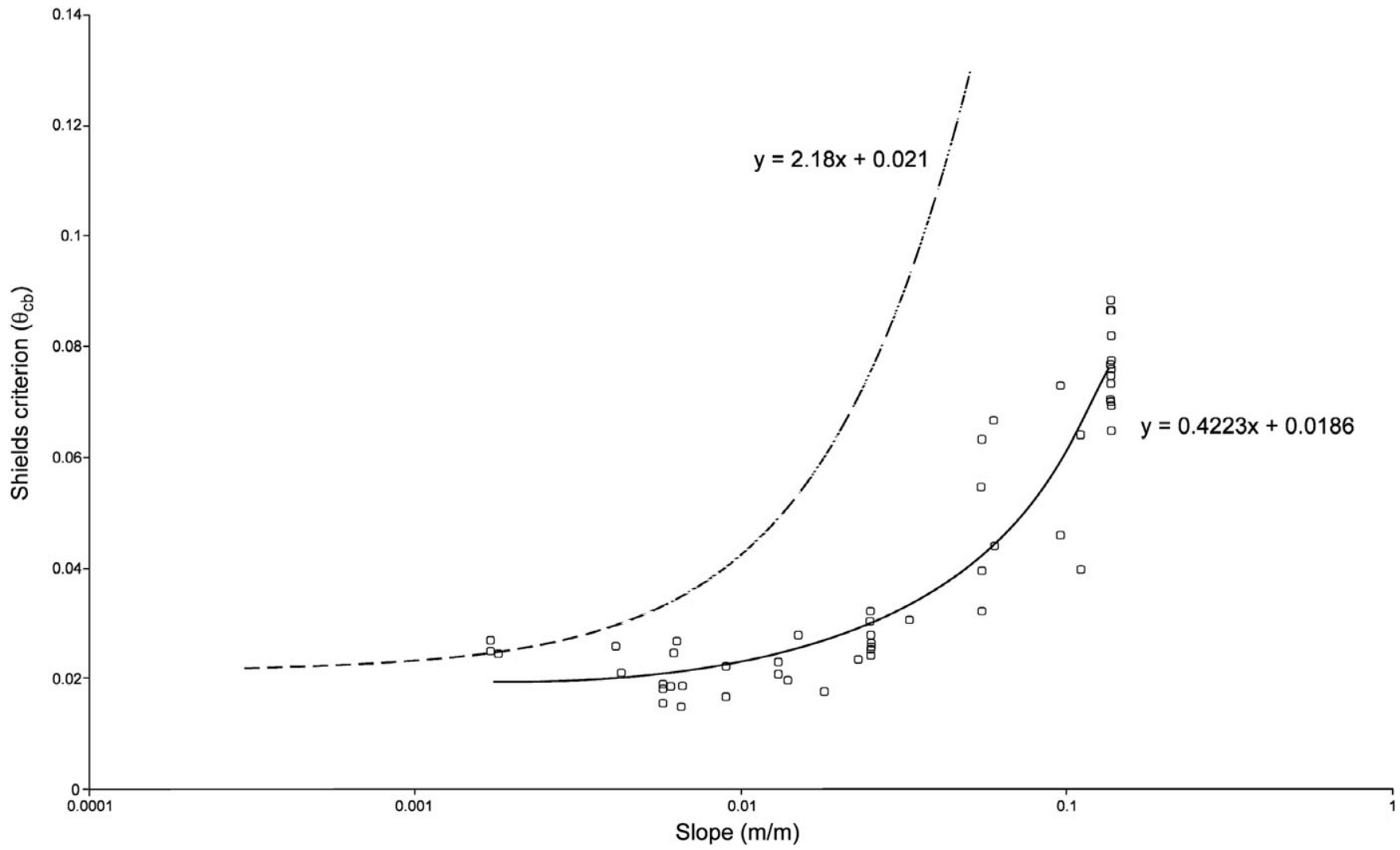

Figure 6. Relationship between the critical shear stress (Shields criterion) needed to transport the mean grain size of the bed $\left(\theta_{\mathrm{cb}}\right)$ and the river slope. The dashed line represents the relationship from Mueller et al. (2005) and the unbroken lines represent the data from this study and those of the Rio Cordon (Lenzi et al., 2006). Critical shear stress has been back calculated from Equation 7.

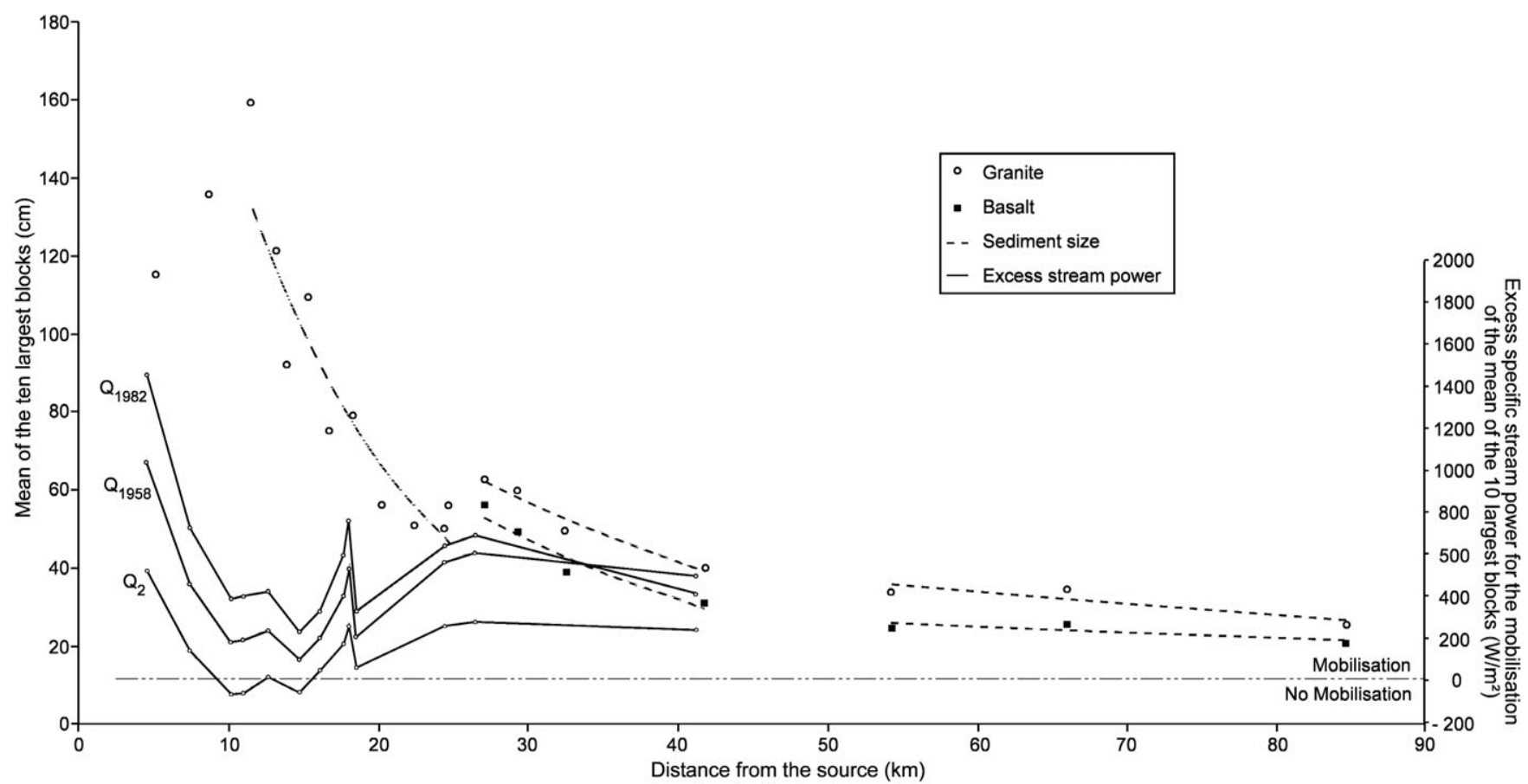

Figure 7. Longitudinal evolution in the Ardeche of the mean of the 10 largest particles (dashed lines) and of the excess specific stream power for the mobilization of the mean of the 10 largest blocks (unbroken lines). The excess stream power is calculated for the 1958,1982 and $Q_{2}$ flood events (recurrence intervals of 10, 500 and 2 years, respectively).

The comparison of the curves in Figure 7 shows that the reach characterized by weak excess stream power (between kilometre 10 and 17 from the source) corresponds to the area where downstream fining is strongest and where the sediment sorting is most efficient. Downstream from the 20th kilometre, excess stream power increases because of an increase in discharge due to a confluence; sediment sorting is then much less efficient. The coefficients of reduction of the curves show that in the first $20 \mathrm{~km}$ hydraulic sorting is the dominant process, i.e. it accounts for $88 \%$ of downstream fining. In the 
second reach attrition plays a larger role and sediment sorting is less efficient (it accounts for only $70 \%$ of downstream fining for the granite section and $84 \%$ for the basalt section).

From these two graphs, one may see that the lower the excess stream power of the river, the more pronounced the downstream fining is. The large particles are in a condition of marginal transport and are therefore not carried as far as smaller particles for which the transport stage is not marginal.

\section{Conclusion}

This study has shown that lichenometry can be a very useful tool in evaluating sediment transport in boulder bed mountainous streams. Indeed, there is a strong correlation between lichen populations and hydrological events, allowing bed dynamics to be archived. Figure 4 shows that sediment motion thresholds may be very different from one boulder bed river to another. Mobilization of a particle of a given size can require up to 10 times more energy in a channel with very big boulders, when compared to a bed with smaller blocks. As suggested by Ferguson (2005) relative grain size and slope seem to be the two main factors influencing critical specific stream power. Until recently critical discharges in boulder bed rivers were frequently estimated using equations such as those of Costa (1983) and Williams (1983). However, recent studies have demonstrated the high variability of these critical thresholds due to riverbed characteristics. By comparing eight boulder bed streams this paper confirms that boulder motion thresholds may be estimated from the equations shown in Table IV, but only within similar environments with comparable slope and sediment characteristics (i.e. Chassezac and Figarella, Ardeche, upper Loire and Fango). Equations 7 and 8 have been constructed to 'universally' predict sediment transport. These relations yield rather good results when applied to the data presented in this study once the values of critical shear stress and the hiding factor $(b)$ are adapted to mountainous boulder streams. These two parameters are variable as they are directly linked to channel slope and relative sediment size, which therefore means that Equations 7 and 8 are also dependent on expert interpretation.

Acknowledgements-This work was funded by the FRIA from the Walloon Region (Belgium) and by the French-Walloon Agreements (TOURNESOL). The authors would like to thank Luca Mao for his remarks on the text and for providing his data from Rio Cordon and Tres Arroyos to build Figure 5. The authors would also like to thank Rob Ferguson and John Pitlick for helpful reviews and Natasha Shields for assistance in translating.

\section{References}

Andrews ED. 1983. Entrainment of gravel from naturally sorted riverbed material. Geological Society of America Bulletin 94: 1225-1231.

Bagnold RA. 1977. Bedload transport by natural rivers. Water Resources Research 13: 303-312.

Bagnold RA. 1980. An empirical correlation of bedload transport rates in flumes and natural rivers. Proceedings of the Royal Society of London A 372: 453-473.

Baker VR, Kochel RC. 1988. Flood sedimentation in bedrock fluvial systems. In Flood Geomorphology, Baker VR, Kochel RC, Patton PC (eds). John Wiley \& Sons: New York; 123-137.

Bravard J-P, Petit F. 1997. Les cours d'eau, Dynamique du système fluvial. Armand Colin: Paris; 222 pp.

Buffington JM, Montgomery DR. 1997. A systematic analysis of eight decades of incipient motion studies, with special reference to gravel-bedded rivers. Water Resources Research 33(8): 1993-2029

Bull WB, Brandon MT. 1998. Lichen dating of earthquake-generated regional rockfall events, Southern Alps, New Zealand. Geological Society of America Bulletin 110(1): 60-84.

Carling P, Tinkler KJ. 1998. Conditions for the entrainment of cuboid boulders in bedrock streams: an historical review of literature with respect to recent investigations. In Rivers Over Rock: Fluvial Processes in Bedrock Channels, Tinkler KJ, Wohl EE (eds), Geophysical Monograph 107. American Geophysical Union: Washington, DC; 19-34.

Chin A. 1998. On the stability of step-pool mountain streams. Journal of Geology 106: 59-69.

Comiti F, Cadol D, Wohl E. 2009. Flow regimes, bed morphology, and flow resistance in self-formed step-pool channels. Water Resources Research 45(4): W04424, 18 pp.

Conchon O, Gauthier A. 1985. Phénomènes naturels exceptionnels en Corse: Intérêt pour l'étude géologique de la période Quaternaire. Bulletin de la Société des Sciences historiques et naturelles de la Corse 104(648): 141-165.

Costa JE. 1983. Paleohydraulic reconstruction of flash-flood peaks from boulder deposits in the Colorado Front range. Geological Society of America Bulletin 94: 986-1004.

Ferguson RI. 2005. Estimating critical stream power for bedload transport calculations in gravel-bed rivers. Geomorphology 70(1): 33-41.

Ferguson RI, Prestegaard KL, Ashworth PJ. 1989. Influence of sand on hydraulics and gravel transport in a braided gravel bed river. Water Resources Research 25: 635-643.

Ferguson RI, Hoey T, Wathen S, Werritty A. 1996. Field evidence for rapid downstream fining of river gravels through selective transport Geology 24(2): 179-182.

Gintz D, Hassan MA, Schmidt KH. 1996. Frequency and magnitude of bedload transport in a mountain river. Earth Surface Processes and Landforms 21(5): 433-445.

Gob F. 2005. La lichénométrie appliquée à l'étude de rivières en gorge en milieu méditerranéen: caractérisation de leurs paramètres dynamiques et de leur évolution géomorphologique durant le Petit Age Glaciaire, PhD Thesis, University of Liège; 307 pp.

Gob F, Petit F, Bravard J-P, Ozer A, Gob A. 2003. Lichenometric application to historical and subrecent dynamics and sediment transport of a Corsican stream (Figarella River - France). Quaternary Science Reviews 22: 2111-2124.

Gob F, Bravard J-P, Jacob N, Petit F. 2005. Determining the competence of mountainous Mediterranean streams using lichenometric techniques. In Geomorphological Processes and Human Impacts in River Basins, Batalla RJ, Garcia C (eds), Proceedings of the International Conference held at Solsona, Catalonia, Spain, May 2004, IAHS Red Book 299. IAHS: Wallingford; 161-170.

Gob F, Jacob N, Bravard J-P, Petit F. 2008. The value of lichenometry and historical archives in assessing the incision of submediterranean rivers from the Little Ice Age in the Ardèche and upper Loire (France). Geomorphology 94(1-2): 170-183.

Hassan MA, Church M, Ashworth PJ. 1992. Virtual rate and mean distance of travel of individual clasts in gravel bed channels. Earth Surface Processes and Landforms 17: 617-627.

Herschy R. 2003. World catalogue of maximum observed floods, IAHS Publications 284. IAHS: Wallingford; 1-285.

Innes JL. 1985. Lichenometry. Progress in Physical Geography 9: $187-254$.

Jacob N. 2003. Les vallées en gorges de la Cévenne vivaraise, Montagne de sable et château d'eau, PhD Thesis, University of Paris IV - Sorbonne; 459 pp.

Jacob N, Gob F, Petit F, Bravard J-P. 2002. Croissance du lichen Rhizocarpon geographicum I.s. sur le pourtour nord-occidental de la Méditerranée, Cévennes, Corses et Pyrénées orientales: observation en vue d'une application à l'étude des lits rocheux et caillouteux. Géomorphologie 4: 283-296.

Jacob N, Gob F, Bravard J-P, Petit F. 2006. Les formes alluviales d'une rivière en gorge, le Chassezac (Cévennes, France). Géomorphologie 1: 3-22.

Keesstra SD, Van Huissteden J, Vandenberghe J, Van Dam O, De Gier J, Pleizier ID. 2005. Evolution of the morphology of the river 
Dragonja (SW Slovenia) due to land-use changes. Geomorphology 69: 191-207.

Knighton AD. 1998. Fluvial Forms and Processes: A New Perspective. Arnold: London; 383 pp.

Lamb MP, Dietrich WE, Venditti JG. 2008. Is the critical shields stress for incipient sediment motion dependent on channel-bed slope? Journal of Geophysical Research F: Earth Surface 113(2): F02008, 20 pp.

Lee AJ, Ferguson R. 2002. Velocity and flow resistance in step-pool streams. Geomorphology 46: 59-71.

Lenzi MA, Mao L, Comiti F. 2006. When does bedload transport begin in steep boulder-bed streams? Hydrological Processes 20: $3517-$ 3533.

Maas GS, Macklin MG, Kirkby MJ. 1998. Late Pleistocene and Holocene river development in Mediterranean steepland environments, Southwest Crete, Greece. In Paleohydrology and Environmental Change, Benito G, Baker VR, Gregory KJ (eds). John Wiley \& Sons: Chichester; 153-165.

Macklin MG, Rumsby BT, Heap T. 1992. Flood alluviation and entrenchment - holocene valley-floor development and transformation in the British uplands. Geological Society of America Bulletin 104(6): 631-643.

Mao L, Uyttendaele GP, Iroumé A, Lenzi MA. 2008. Field based analysis of sediment entrainment in two high gradient streams located in Alpine and Andine environments. Geomorphology 93(34): 368-383.

Montgomery DR, Buffington JM. 1997. Channel-reach morphology in mountain drainage basins. Geological Society of America Bulletin 109(5): 596-611.

Mueller ER, Pitlick J, Nelson JM. 2005. Variation in the reference Shields stress for bed load transport in gravel-bed streams and rivers. Water Resources Research 41(4): 1-10.
Parker G, Klingeman PC, Mc Lean DG. 1982. Bedload and size distribution in paved gravel-bed streams. Journal of the Hydraulics Division - ASCE 108(HY4): 544-571.

Petit F, Gob F, Houbrechts G, Assani AA. 2005. Critical unit stream power in gravel-bed rivers. Geomorphology 69(1-4): 92-101.

Recking A. 2009. Theoretical development on the effects of changing flow hydraulics on incipient bed load motion. Water Resources Research 45(4): W04401, 16 pp.

Robert A. 2003. River Processes, an Introduction to Fluvial Dynamics. Arnold: London; $214 \mathrm{pp}$.

Smirnova TY, Nikonov AA. 1990. A revised lichenometric method and its application dating great past earthquakes. Arctic and Alpine Research 22(4): 375-388.

Vericat D, Batalla J. 2007. Fractional bedload transport during small floods in a regulated gravel-bed river. Zeitschrift für Geomorphologie 51(2): 227-240.

Werritty A. 1992. Downstream fining in a gravel-bed river in southern Poland: lithologic controls and the role of abrasion. In Dynamics of Gravel-bed Rivers, Billi P, Hey RD, Thorne CR, Tacconi P (eds). John Wiley \& Sons: Chichester; 333-350.

Williams GP. 1983. Paleohydrological methods and some examples from Swedish fluvial environments. Geografiska Annaler 65A(3-4): 227-243.

Winchester V, Chaujar RK. 2002. Lichenometric dating of slope movements, Nant Ffrancon, North Wales. Geomorphology 47(1): $61-74$.

Wohl EE. 2000. Mountain Rivers, Water Resources Monograph 14. American Geophysical Union: Washington, DC; 320 pp.

Wolman MG. 1954. A method of sampling coarse river-bed material. Transactions of American Goephysical Union 35(6): 951956. 